\title{
Gray, Lila Ellen. Fado Resounding: Affective Politics and Urban Life. Durham and London: Duke University Press, 2013.
}

Lila Ellen Gray's Fado Resounding: Affective Politics and Urban Life has the feel of a magnum opus. Ambitious in its breadth, it is clear from the get-go that this study is no small undertaking. Indeed, this is the first full-length ethnography of Portuguese fado published in English. Gray does not hedge by underpromising, and by the final afterword following six meticulously researched and theorized chapters, she has delivered a major contribution to fado scholarship.

It is surprising how little scholarship dedicated to Portuguese music exists in English. The reader may feel the weight of this scarcity and the resultant scholarly responsibility in Gray's book. Gray tackles amateur fado from many different angles, breaking new ground while in constant dialogue with multiple bodies of literature. There is a "leave no stone unturned" feeling about this study, which in less skilled hands might have led to analytical overextension or thinness of treatment. But this is not the case here. Lila Ellen Gray writes robustly argued chapters dedicated to fado pedagogy, the interpolation of historical narratives in fado discourse and practice, fado vocal styling, the importance of place in fado lyrics and lore, the relationship between gender and genre, and finally fado celebrity and fandom.

Gray's introduction places her study at the nexus of genre, expressive practice, affect, and place. While her field site is limited to amateur performance circuits, cutting a manageable ethnographic slice from the fado world as a whole, she is concerned not only with the micro dynamics of this particular musical community but also with fado cosmology and the potential universality of affect. Her introduction provides a thumbnail sketch of fado's formal characteristics-instrumentation, taxonomies of song type, range of lyrical content, and features of vocal styling. She also catalogues different types of fado venues in addition to providing a summary of the debate over fado's origins.

Fado Resounding's first chapter deals with fado pedagogy and the thorny issues surrounding fado's mythic "unlearnability." Gray adroitly compares her own experience of fado learning both in the field and during formal lessons at the Museu do Fado with life story narratives from amateur fadistas to understand 
how and why fado singing is considered to be something one is born with, not something one can acquire through instruction. An important and original feature of this chapter is Gray's formulation of "structures of listening" where she discusses various qualities of silence which undergird fado performance and the strict expectations for audience expression and comportment.

In the following ambitious chapter dedicated to fado's dialogic relationship to history, Gray explores the ways in which the remainders of Portuguese empire are narrated through fado stories. She engages theories of lusotropicalism and what she terms Lisbon's "everyday colonial" in order to grapple with slippage, romanticism, blind spots and concerted forgettings and rememberings-work that fado does in order to narrate its own self-reflexive history as an urban song form with ties to traditions from the Middle East, Iberia, Africa and Brazil. She documents scholarly theses about these historical relationships, alongside ethnographic testimony attesting to cross-cultural affinities people hear when listening to fado, alongside song lyrics which create a mythology of discovery-era fado origins. Gray allows these different narrative trajectories to exist side by side, shaking out what they mean to the haphazard project of building a nation's historical memory through the prism of song.

Chapter Three, "Fado's City," explores the Lisbon neighborhoods that loom large in fado cosmology, theorizing an "acoustemology" of place. She historicizes a discussion of place-based lyrics by noting the ways in which Estado Novo censors created a sanitized portrait of urban neighborhoods. She also offers contrapuntal examples of lyrical tropes of abandonment and degradation in place-name fados written after the revolution.

In Chapter Four, Gray's experience as a classically trained musician bears fruit as she undertakes a careful analysis of vocal styling against the backdrop of theories of improvisation. She compares multiple field recordings of José Manuel Osório singing the same fado. Working with musical notation of these recordings, she points to ranges of difference as well as the similar "scaffolding" that undergirds improvised vocal styling.

Chapters Five and Six collaborate to uncover the workings of gender in fado practice, repertoire choice, lyrics and sociability. Gray discusses the dominance of the female voice in Lisbon's fado expression against the backdrop of 
male instrumentalists' role as fado experts and guides. She dedicates a section to gender "play" and the relationship between celebrity and fado in drag. Lastly, the final chapter focuses on the role Amália Rodrigues has played in fado practice, fado mythology, and the creation of Portugal's national image. She explores the ambiguity of Amália's political affiliation, as well as the interworkings of fan devotion and mimesis among "Amalianos" and the other fadistas who have sung her repertoire in varying contexts. The book's final contents include an Afterword, two Appendices containing musical notation of Osório's vocal performances, and a lengthy endnote section.

In Fado Resounding, Gray does not shy away from taboo topics or thorny contradictions, and this, I think, is one of the great merits of her book. Gray meets the challenge of studying a genre which has undergone many dramatic changes in its almost two centuries of existence, head on. Her willingness to embrace ambiguity and contradiction, rather than bully her analysis into hollow exercises of side-taking, should win the reader's trust; the book provides different angles on the major problematics and debates surrounding fado origins, history and practice, so that readers can decide for themselves. It also engages the exciting body of work coming out of Portugal on fado and other forms of Portuguese cultural production, rarely so attentively summarized and grappled with in English. Thus, her study constitutes not only a nitty-gritty grassroots portrait of an urban song form played out in the clubs and taverns of Lisbon's amateur circuits, but also a reference work for important Portuguese-language scholarship otherwise inaccessible to monolingual readers in the Anglophone world. Lila Ellen Gray's many years of good, old-fashioned fieldwork-time-intensive methods which may be losing ground these days as digital technologies enable a new brand of armchair ethnography-has produced a highly nuanced, original contribution to knowledge around Portugal's legendary "national song."

\section{Kimberly DaCosta Holton}

Rutgers University-Newark 